\title{
MODEL OF COMMUNICATIVE ENGLISH SYLLABUS FOR STUDENTS OF HOTEL DEPARTMENT AT SMK N 7 BENGKULU
}

\author{
Ayu Anisa Sartika \\ University of Bengkulu, \\ ayuanisasartika77@gmail.com \\ Hilda Puspita \\ University of Bengkulu, \\ puspitahilda@gmail.com \\ Imranuddin \\ University of Bengkulu, \\ imranulama@gmail.com
}

\begin{abstract}
This study was designed as a developmental research which was aimed at designing communicative English syllabus for students of Hotel Department at SMK N 7 Bengkulu. The researcher used needs analysis to find out the students' needs of English. The instrument used was a set questionnaire items to collect the data. The population of this study was students and English teachers at SMK N 7 Bengkulu and hotel staff of Nala Seaside Hotel Bengkulu as well. The samples of this study were selected with two techniques sampling. The first technique sampling was random sampling for 80 students. The second technique sampling was total sampling for 3 English teachers and 12 hotel staff. The result of the study showed that listening skill gained 94\%, speaking skill gained $91 \%$, reading skill gained $74 \%$, and writing skill gained $68 \%$. From the result of data analysis, a syllabus was designed based on communicative approach and it had been tried out for three times.
\end{abstract}

Key words: syllabus development, communicative English syllabus

\begin{abstract}
Abstrak
Penelitian ini merupakan penelitian pengembangan yang bertujuan untuk merancang silabus bahasa Inggris berbasis pendekatan komunikatif yang ditujukan untuk siswa perhotelan di SMK N 7 Bengkulu. Analisis kebutuhan digunakan dalam penelitian untuk mengetahui kebutuhan berbahasa Inggris siswa perhotelan. Instrumen yang digunakan adalah kuesioner. Populasi penelitian adalah siswa dan guru bahasa Inggris di SMK N 7 Bengkulu serta staf hotel Nala Seaside Hotel Bengkulu. Sampel penelitian menggunakan dua teknik sampling. Teknik sampling yang pertama menggunakan random sampling untuk 80 siswa. Sampel teknik kedua menggunakan total sampling untuk 3 guru bahasa Inggris dan 12 staff hotel. Hasil data analisis menunjukkan bahwa listening skill mencapai 94\%, speaking skill mencapai 91\%, reading skill mencapai $74 \%$, dan writing skill mencapai $68 \%$. Berdasarkan hasil data analisis, peneliti mendesain silabus berbasis pendekatan komunikatif yang sudah diuji coba ke siswa perhotelan di SMK N 7 Bengkulu.
\end{abstract}

Kata kunci: pengembangan silabus, silabus Bahasa Inggris berbasis komunikatif 


\section{INTRODUCTION}

The development of tourism industry in Indonesia has increased rapidly. According to Central Bureau of Statistic, the number of tourist arrivals in Indonesia reached 8.8 million people in 2014 and compared with that in 2015, it grew by 9.4 percent. This high number of tourist arrivals influences the growth number of hotel in Indonesia. It means that the work forces who work in hotel's field play an important role to maintain the hotel qualities in Indonesia especially in service.

English becomes really important for the work forces of tourism industry, especially for those who work in hotel field because they use English to communicate with foreign tourists from all over the world. From that reason, the government builds vocational school as a formal education for the students who are expected to be professional hotel staff and master English after they finish their study.

Building vocational knowledge and skills is one of the goals that students of vocational school have to envision. This has a significance implication for English language programs, which provide to differing needs of diverse groups of vocational students. In response to this, Vogt and Kantelinen (2013) states that vocationally oriented language learning programs aims to provide students with an English course integrated with vocational content.

In a course of vocational school especially for hotel program, English is taught to give students the communicative use. They need certain English that called English for Specific Purpose. In English subject for Specific Purposes, the students require English related to their future jobs. However, that statement will not work on successfully without a good syllabus because it helps teachers to make learning activity becomes successful. A syllabus becomes a clear guideline for a teacher to make a lesson. It describes the progress of teaching and learning activity. In addition, Hutchinson and Waters (1987) say that a syllabus does not only show the teachers and students their learning destination but also how they can reach their goal. Having a syllabus in fact, is something unavoidable for teachers.

However, Hotel Department students need English syllabus that can fulfil their language need. Those students need to be exposed to and interact in real-life situations using target language, which is called communicative activities. According to Richard and Rodgers (1986), communicative activities emphasizes on communication and reallife situation.

Munby (1978), explains that communicative syllabus gives more systematic attention to the communication needs of the learners. It means that the setting of instruction has to be planned and the content of the syllabi are developed based on the practical constraint of any given situation. It provides the learners to learn more efficiently if the learning track is in a good structure and if it is not, the learners will not be able to reach their goal in the scheduled time. Therefore, it is important to develop a communicative English syllabus which emphasize on practical skills which can meet the demand of the working condition in the tourism industry especially in hotel field.

In Bengkulu, SMK N 7 is the only vocational school that has hotel program. However, that program is relatively new because it is established since 2014. In fact, the English subject that has been taught at SMK N 7 Bengkulu is not relevant to the context in the hotel. The English subject is for general English which means English subject in SMK N 7 Bengkulu are not relevant with the students major. It means that the current English syllabus in SMK N 7 Bengkulu 
also provides general English for their students.

The problems above cause the language proficiency received by students will be different with cases that they will find at work if teacher still use the materials that out of the context from their study program. In addition, the English skills that they got from learning activities might not include the criteria of hotel companies who are going to hire them after they graduate. Therefore, developing a communicative English syllabus for students of Hotel Department is important.

Based on the background above, there are two problems of English subject at hotel department of SMK N 7 Bengkulu. First is the English subject that has been taught at Hotel Department of SMK N 7 Bengkulu does not meet the needs of students in learning English. Second is the current English syllabus at Hotel Department of SMK N 7 Bengkulu is not relevant to students' needs. From that problems, there are two research objective of this study first is to find out the students' needs of English, second is to design the model of communicative English syllabus that relevant to the needs of students of Hotel Department at SMK N 7 Bengkulu.

There are two studies that have done almost similar with this topic. Setyaningsih (2009) is conducted a study about the needs of learning English for pre-flight attendant. Her study focuses on designing English syllabus based on the learners needs'. The second research is by Helida (2015) about model of authentic English teaching materials for law faculty students. Her study focuses on designing English authentic materials based on English needs of law students. As a conclusion, the first research focuses on designing the communicative English syllabus for pre-flight attendant. On the other hand, the second research focuses on designing the authentic English materials for students of law faculty.
Same with previous study, this study is a kind of developmental research which focuses on the needs of learning English. However, there are few studies that conducted to designing communicative English syllabus.

Different from those two mentioned research, this research investigate the students needs of English in SMK N 7 Bengkulu in order to design the communicative English syllabus based on their needs. It is expected to be guideline to English teachers in designing lesson plan through practical activities contained in the syllabus. It is also expected to give some input to the curriculum developer and syllabus designer to design the ESP syllabus.

\section{METHOD}

This study was a developmental research which was aimed to investigate the needs of English language learning for students' hotel study program. Furthermore, based on the needs, the communicative English syllabus was designed and tried out.

Following the Sugiyono's theory, the researcher designed the communicative English syllabus. According Sugiyono (2013), developmental research consists of some steps as follows:

1. Collecting data (needs analysis)

2. Designing the product

3. Validating the product

4. Revising the product

5. Trying out the product

6. Revising the product

7. Final product

The population of this research were the students, the English teachers at Hotel Department of SMK N 7 Bengkulu and also hotel staff in Nala Sea Side Hotel. For this research, the sample consisted of 80 students, 3 English Teachers, and 12 hotel staff at Nala Sea Side Hotel Bengkulu.

To collect the data, this study used questionnaire. The questionnaire was divided into four kind questionnaires to find out the needs of English by hotel 
students. The questionnaire for hotel students focused on students' needs of English. Meanwhile, there were two questionnaires for English teachers; the first focused on students' needs of English based on teachers' point of view, the second focused on English teachers' responses toward the learning activity in classroom using the syllabus. Then, the questionnaires for hotel staff focused on the English skills that frequently used during work as hotel staff.

The questionnaires were analyzed by using percentage formula as follow:

$$
\begin{aligned}
& \mathrm{P}=\frac{\mathrm{f}}{\mathrm{n}} \times 100 \% \\
& \mathrm{P}=\text { Percentage of participant } \\
& \text { response toward questionnaire } \\
& \mathrm{f}=\text { frequency of the same answer } \\
& \mathrm{n}=\text { number of participants }
\end{aligned}
$$

The result of the data which taken from the questionnaire became the basic steps for the researcher to go to design the syllabus. The researcher took some notes of the important points, put each data to the right headings then design the syllabus which suits the data gathered.

\section{RESULTS AND DISCUSSIONS a. Result of Needs Analysis}

The data were taken from need analysis by using questionnaires that had been distributed to 100 respondents (students, English teachers, and hotel staff). The results of the questionnaires can be seen in diagrams below:

\section{Diagram 1}

The Result of Needs Analysis of Listening Skill
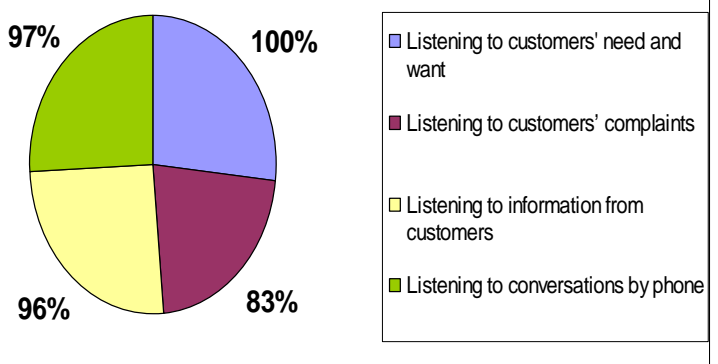

There were some hotel staff's duties in a part of listening skill that becomes the needs of English for students of Hotel Department. The needs of English were listening to customers need and want, listening to customer's complaint, listening to information from customers, and listening to conversation by telephone. Based on diagram above, listening to customers' need and want was the first most needed by the hotel students at SMK N 7 Bengkulu. It reached percentage of $100 \%$ that means all of respondents chose this skill. Then, the second most needed was listening to conversation by telephone, it can be seen from the diagram that the percentage was $97 \%$. The third most needed reached $96 \%$ which was 76 respondents chose listening to information from customers. Then, the last percentage reached $83 \%$ that means 67 respondents chose the skill of listening to customers' complaint. As a conclusion, the highest percentage that reached $100 \%$ was listening to customers need and want. On the other hand, the lowest percentage that reached $83 \%$ was listening to customers' complaint. However, since the percentage of students' need of English was above 80\%, all of those needs of English would be put in the design of communicative English syllabus. 


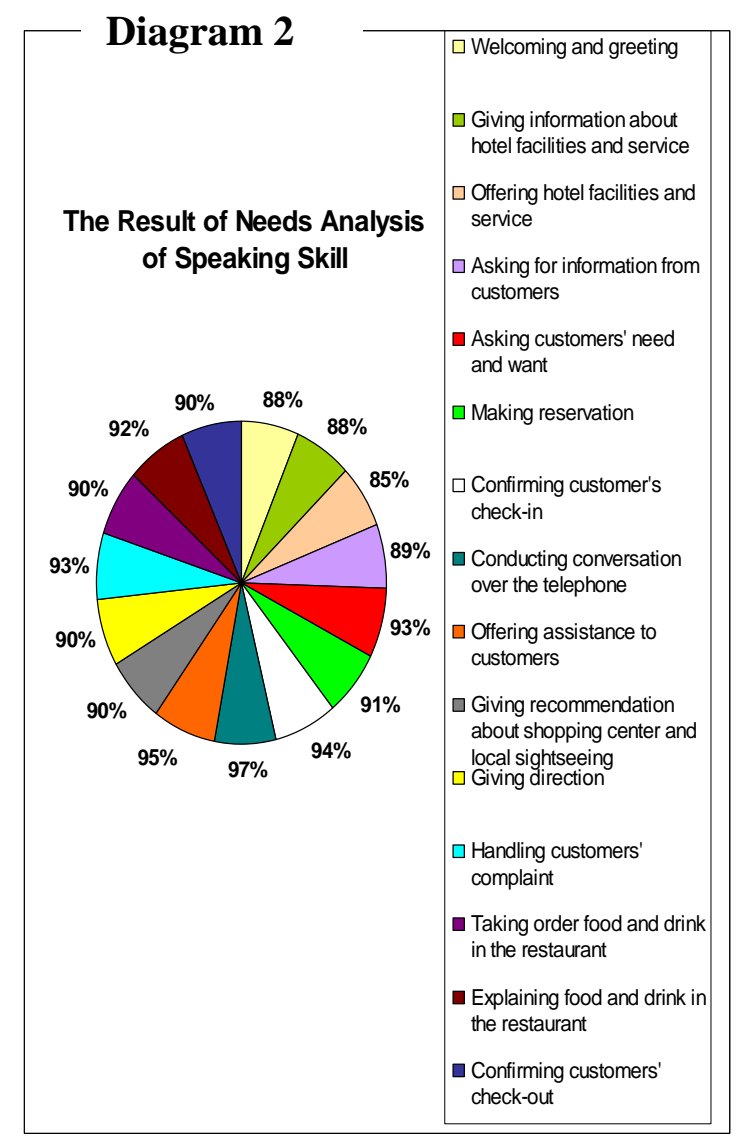

There were some hotel staff duties in a part of speaking skill such as; welcoming and greeting, giving information about hotel facilities and service, offering hotel facilities and service, asking for information from customers, asking customers' need and want, making reservation, confirming customer's check-in, conducting conversation over the telephone, offering assistance to customers, giving recommendation about shopping centre and local sightseeing, giving direction, handling customers' complaint, taking order food and drink in the restaurant, explaining food and drink in the restaurant, confirming customers' checkout.

Based on the diagram above, the need of English that had the highest percentage was conducting conversation over the telephone which reached $97 \%$. Then, the second highest percentage that reached $95 \%$ was offering assistance to customers. Then, the third highest percentage that reached $94 \%$ was confirming customers' check-in. Next, handling customers' complaint and asking customers' need and want had the same percentage. Both skills reached the percentage of $93 \%$. Then, the need of English that had percentage of $92 \%$ was explaining foods and drinks in the restaurant. Next was making reservation with the percentage of $91 \%$. Then, there were four needs of English that reached percentage of $90 \%$. They were giving recommendation about shopping centre and local sightseeing, giving direction, taking order the foods and drinks in the restaurant and confirming customers check-out. Asking for information from customers had the percentage of $89 \%$. Then, two needs of English that reached percentage of $88 \%$ were welcoming and greeting, and giving information about hotel facilities and services. Then, the lowest percentage of needs of English with the percentage of $85 \%$ was offering hotel facilities and services. As a conclusion, it was important to put all of those needs of English as in a model of communicative English syllabus because the percentages of needs of English were above $80 \%$.

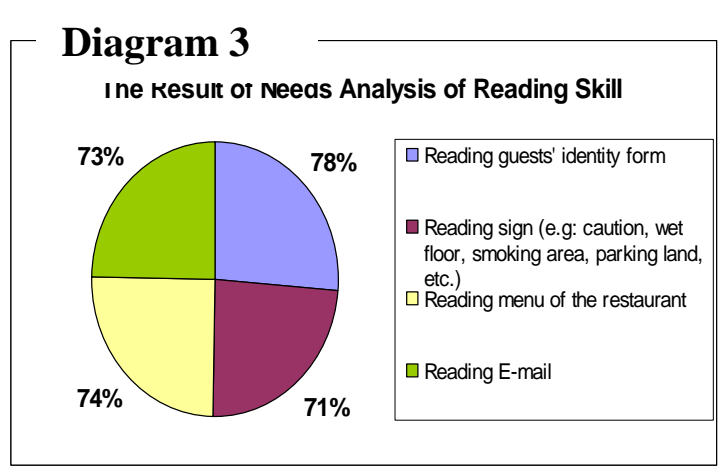

There were some hotel staff's duties in a part of reading skills. It becomes the needs of English for students of Hotel Department. The diagram above showed that reading guests' identity form reached the percentage of $78 \%$. Then, the second percentage was reading restaurant menu that reached $74 \%$; the third percentage was reading E-mail that reached $73 \%$; and the last percentage was reading sign that reached $71 \%$. As the conclusion, the 
highest percentage of analysis of reading skill was reading guests' identity form. On the other hand, the lower percentage was reading sign. Due to the averages of those skills above $70 \%$, the entire needs of English would be put into the design of communicative English syllabus.

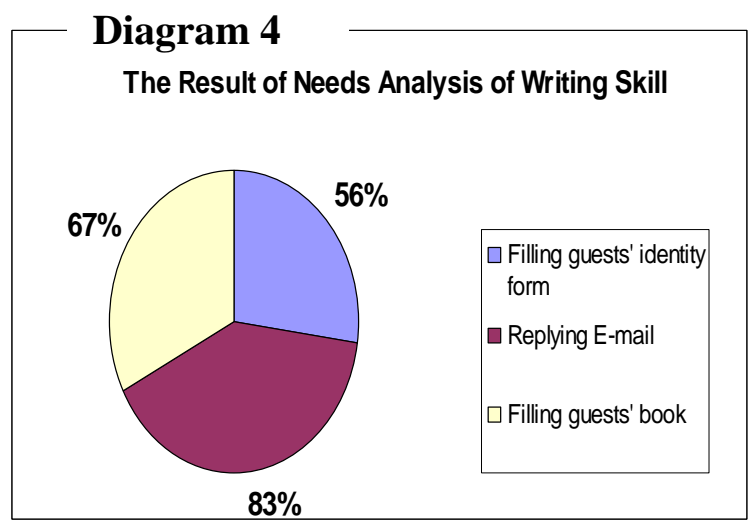

Based on diagram above, there were some duties of hotel staff in a part of writing skill such as; filling guest's identity form, replying E-mail, and filling guests' book. From those needs of English, replying E-mail was the most chosen by the respondents. 75 respondents chose this skill which means the percentage of this skill was $83 \%$. Then, in second place, it can be seen from the diagram that 72 respondents chose filling guest's book which the percentage reached $67 \%$. In third place, 66 respondents chose filling identity form which means its percentage was $56 \%$. As a conclusion, the needs of English writing skill with the highest percentage was replying E-mail. On the other hand, the lowest percentage was filling identity form. However, all of those needs of English would be put into design a communicative English syllabus because the percentages of students' needs of English were above $75 \%$.

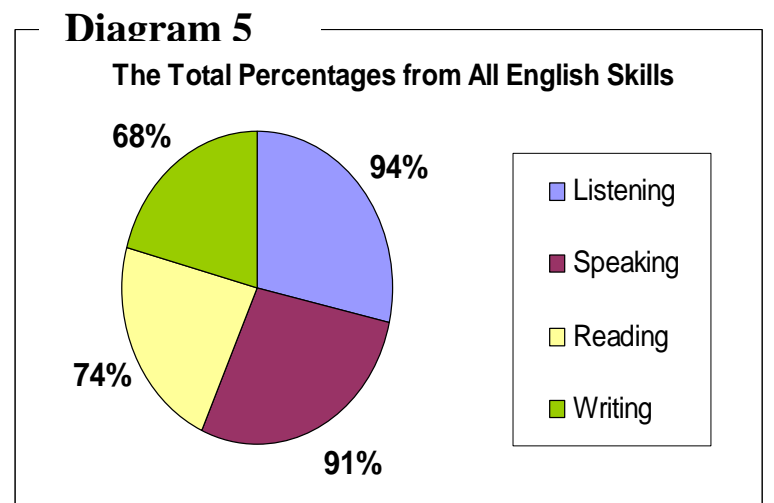

The diagram above is the result of the total percentage from all English skills. As seen above, listening skill had percentage of $94 \%$, speaking skill had percentage of $91 \%$, reading skill had percentage of $74 \%$, and writing skill had percentage of $68 \%$. It reveals that listening and speaking skills were the most needed for the students of Hotel Department rather than reading and writing skill.

\section{b. Result of Designing the Syllabus}

After getting the data from the needs analysis using questionnaire, the researcher designed a communicative English syllabus for the first draft (the result of syllabus for the first draft can be seen in the Appendix 7). The syllabus was set for English subject for students of Hotel Department. It was designed for one semester which consisted of ten topics about the hotel context. The type of syllabus was notional-functional syllabus which used communicative approach and some compilation of language function that were performed and expressed during the learning and teaching process. The examples of language functions were among others greetings and welcoming customers, explaining about hotel facilities, handling customers' complaint, offering assistance, inquiring customers' need and want, and so on.

The design of the syllabus consisted of course identity, course description, course objective, approach, topics, standard competency, basic competence, indicators, learning activities, time 
allocation, learning assessment, and sources. Before designing the first draft of the syllabus, the researcher determined the topics, skills, and indicators based on the result of questionnaire and library research. The topics, skills, and indicators were designed as guideline for researcher to make the researcher easier to design the syllabus. The topics, skills, and indicators can be seen in following table:

Table 1. Topics and Indicators

\begin{tabular}{|c|c|c|}
\hline NO. & TOPICS & INDICATORS \\
\hline 1. & $\begin{array}{l}\text { Welcoming } \\
\text { and } \\
\text { Greeting } \\
\text { Customer }\end{array}$ & $\begin{array}{l}\text { 1.1 Welcoming and } \\
\text { greeting the } \\
\text { customers hotel with } \\
\text { appropriate } \\
\text { language expression }\end{array}$ \\
\hline 2. & $\begin{array}{l}\text { Making } \\
\text { Reservation }\end{array}$ & $\begin{array}{lr}2.1 & \begin{array}{l}\text { Asking } \\
\text { customer's } \\
\text { details }\end{array} \\
\text { information } & \text { and } \\
2.2 & \text { Giving } \\
\text { information } & \text { about } \\
\text { room's } & \text { details } \\
\text { (room's size, room's } & \\
\text { rate, etc.) } & \end{array}$ \\
\hline 3. & $\begin{array}{l}\text { Introducing } \\
\text { Hotel } \\
\text { Features } \\
\text { and Service }\end{array}$ & $\begin{array}{l}3.1 \text { Recommending } \\
\text { hotel features and } \\
\text { service to customers } \\
3.2 \text { Persuading hotel } \\
\text { features and service } \\
\text { to customers }\end{array}$ \\
\hline 4. & $\begin{array}{l}\text { Checking- } \\
\text { in }\end{array}$ & $\begin{array}{l}4.1 \text { Checking } \\
\text { reservation } \\
4.2 \text { Confirming } \\
\text { customers room's } \\
\text { reservation }\end{array}$ \\
\hline 5. & $\begin{array}{l}\text { Reading } \\
\text { and Writing } \\
\text { E-mail }\end{array}$ & $\begin{array}{l}\text { 5.1 Reading E-mail } \\
5.2 \quad \text { Writing } \\
\text { (replaying) E-mail }\end{array}$ \\
\hline 6. & $\begin{array}{l}\text { Dealing } \\
\text { with }\end{array}$ & 6.1 Inquiring about \\
\hline
\end{tabular}

\begin{tabular}{|c|c|c|}
\hline & \multirow[t]{2}{*}{ Customers } & customers' needs \\
\hline & & $\begin{array}{lr}6.2 & \text { Offering } \\
\text { assistance } & \text { to } \\
\text { customers } & \\
6.3 \quad \text { Handling } \\
\text { customer's } \\
\text { complaint }\end{array}$ \\
\hline 7. & $\begin{array}{l}\text { Dealing } \\
\text { with } \\
\text { Customers } \\
\text { (over the } \\
\text { telephone) }\end{array}$ & $\begin{array}{l}\text { 7.1 Making } \\
\text { reservation over the } \\
\text { telephone } \\
\text { 7.2 Responding to } \\
\text { the customers' call } \\
\text { who asking for } \\
\text { services (cleaning } \\
\text { and laundry, } \\
\text { ordering meals and } \\
\text { drinks) }\end{array}$ \\
\hline 8. & $\begin{array}{l}\text { Sightseeing } \\
\text { and } \\
\text { Shopping }\end{array}$ & $\begin{array}{l}8.1 \text { Giving } \\
\text { recommendation } \\
\text { about shopping } \\
\text { centre and } \\
\text { sightseeing } \\
8.2 \text { Giving direction }\end{array}$ \\
\hline 9. & $\begin{array}{l}\text { Serving } \\
\text { food and } \\
\text { beverages } \\
\text { in } \\
\text { restaurant }\end{array}$ & $\begin{array}{l}\text { 9.1 Taking order of } \\
\text { foods and drinks in } \\
\text { restaurant } \\
\text { 9.2 Explaining } \\
\text { foods and drinks in } \\
\text { restaurant }\end{array}$ \\
\hline 10. & $\begin{array}{l}\text { Checking- } \\
\text { out }\end{array}$ & $\begin{array}{l}10.1 \text { Confirming } \\
\text { customers to check- } \\
\text { out from the hotel }\end{array}$ \\
\hline
\end{tabular}

The first step of designing the syllabus was determining the course identity, the course description, and the course objective. It provided the information related to the use of the syllabus. In course identity the researcher filled the title of the course, the students' grade, and the course semester. Then, in course description, it was explained about the aim of the course in communicative English syllabus. It aimed to provide the students with practical knowledge of 
communicating with hotel customers using appropriate language expression. For course objective, the students were expected to use appropriate language expression while communicating and interacting with hotel customers.

The second step of designing the syllabus was determining the standard competency. Standard competency was a description of the knowledge, skills, and attitudes that must be mastered after the students study English as the subject at SMK. The standard competency for communicative English syllabus was the students were able to express meaningful utterances of interpersonal and transactional conversation in the hotel context.

The third step of designing the syllabus was determining the basic competence. Basic competence was the knowledge, skills and attitudes that students should achieve to show that the students have mastered the standard competency. The basic competence followed the topics that had been designed before, for example: Students are able to welcome and greet the hotel customers using appropriate language expression. Then, after determining the basic competence, the researcher identified the indicator. Indicator was the marker of students learning achievement based on the basic competence. For example, the students are able to give information about hotel facilities and services to hotel customers.

The next step in designing the syllabus was arranging the learning materials. The learning materials in syllabus consist of language function, grammar, language expression, and vocabulary related to basic competence and indicator. The researcher gathered the sources from internet and text book to arrange the learning materials.

The next step of designing the syllabus was determining the learning assessment. In communicative English syllabus, the learning assessment used oral assessment through role play and group discussion. After designing the learning assessment, the researcher determined time allocation. Time allocation in syllabus for each meeting was $2 \times 45$ minutes. It adjusts with time allocation in SMK N 07 Bengkulu.

Then, the next step was determining the learning sources. The Learning sources were the reference materials used for instructional activities in the form of print and electronic media. In communicative English syllabus, the researcher used the video (electronic media) relates to activity in the hotel. The syllabus offered several sources that could be obtained during learning and teaching process. The sources were mostly obtained from the internet as it provided websites from hotel industry around the world and some videos that had been downloaded from www.youtubevideos.com. These sources would support the learning materials and learning activities during the learning and teaching process in classroom.

\section{c. Result of Trying out the Syllabus}

After the second draft of syllabus was validated by the experts, the syllabus had been tried out to the students by the researcher and two English teachers at SMK N 7 Bengkulu. The researcher and the English teachers implemented some of topics in syllabus in classroom as it was already elaborated in lesson plans (lesson plan can be seen in Appendix 5). The topics that had been taught to the students were "Making Reservation", "Check-in", and "Check-out".

The first topic was "Making Reservation". It had taught to the students by the researcher on April, $3^{\text {rd }} 2017$. The topic was aimed to make the students were able to deal with hotel guests who want to reserve a hotel room. The topic discussed about asking for information to hotel guests that want to stay at the hotel. It also discussed about giving information to the hotel guests about hotel rooms and 
the others hotel facilities. In this topic, the students were introduced to the language function of making hotel room's reservation and some vocabularies related to the topic.

Then, the second topic was "Checkin" that had done by the English teacher on April, 26 $6^{\text {th }}$ 2017. This topic discussed about language functions and some vocabularies related to the topic. It was aimed to make the students able to communicate with hotel guest when they check-in to the hotel. The students learned how to check rooms that had been reserved and how to confirm hotel guests to stay in the hotel.

The third topic was "Check-out" that had implemented by the English teachers on Mei $2^{\text {nd }} 2017$. It was aimed to make the students able to deal with hotel guests who want to check-out from the hotel. The topic discussed about how to confirm the hotel guests' check-out. In this topic, the students were introduced to the language function of check-out from the hotel and some vocabularies related to the topic.

The learning activities in classroom were used communicative approach. According to Richards and Rodgers (2001), communicative activity in classroom divided into two sections, precommunicative activity and communicative activity. Precommunicative activity was done by the students and English teachers before the communicative activity. It was focus on structural activity which means the students would learn about grammar, vocabularies, and language expression toward the target language. Meanwhile, communicative activity was done after the students understood about grammar, vocabularies, and language expression that had teach by the English teachers in pre-communicative section. In communicative section, the students focused on social interaction which meant they used four English skills to reach communicative goal. They forced to produce language in classroom like in real hotel situation by using target language.

There were some steps in precommunicative activity. First was conducting the ice breaking in classroom to make sure that the students in good condition before starting the lesson. Then, the second step was building the students background knowledge about the topic. The next step was showing a video related to the topic. The video was aimed to give the example for students about language functions related to the topic. Then, the researcher showed the examples of dialogue about the topic.

After pre-communicative activity, the next step was communicative activity. In communicative activity, the students practiced the language as in real life situation by role play. The students divided into some groups, on each groups consist of 4 until 5 students. Then, the students make a dialogue using language expression that had been explained. At the end of the class, the students practiced the dialogues in front of the class in group.

\section{DISCUSSION}

\section{a. Students needs of English}

The researcher had done the data analysis that its result showed the English skills needed by the students of Hotel Department at SMK N 7 Bengkulu. Those English skills (listening, speaking, reading, and writing) divided into 26 English sub-skills for hotel working situation. Those English sub-skills were used as a basis for developing the communicative English syllabus for students of Hotel Department at SMK N 7 Bengkulu.

Based on the diagram 4.1, there were four English sub-skills of listening skill. The result of data analysis showed the average of percentage from those subskills was the highest if compared with the others skills. It also supported by the result of data analysis from hotel staff 
that listening skill was the most frequently used during working at the hotel. In contras, as it seen in the diagram 4.2 , the result of data analysis showed the average of percentage from speaking subskills was the second most needed by the students after listening skill. This result was also supported by the result of data analysis from hotel staff. It showed that speaking skill was the most frequently used during working as staff hotel.

From the diagram 4.3 and 4.4 , it showed the English sub-skills of reading and writing skills. The result showed that the average of percentage from reading sub-skills was the third skills needed while the average of percentage from writing sub-skills was the last skills needed by the students of Hotel Department.

Based on the result of data analysis above, the English skills that obtained the most attention were speaking and listening skills. It was also supported by questionnaires from hotel staff that showed speaking and listening skills were the frequently used during working in the hotel. Both skills also play an important role in handling all kinds of communication that happen in the hotel. Speaking skill was needed to give the hotel customers clearer explanations about what happen in the hotel. Meanwhile, listening skill was useful to avoid miscommunication by giving full attention while listen to what hotel customers needs and wants.

However, writing and reading skills also obtained some attention from the respondents but not much as listening and speaking skills. These skills were also having important role in communicative activities in classroom. Even though the communicative classroom emphasize on communicating which means listening and speaking skills have the dominant role in learning activities, but reading and writing skills were used by the students while they study about language expressions and vocabularies. They need to know how to read the language expressions and vocabularies and how to write it down in a correct way. So, listening, speaking, reading, and writing skills have important role to reach communicative goal.

\section{b. Communicative English Syllabus}

The communicative English syllabus was designed based on the result of English skills and sub-skills that needed by the students of Hotel Department. Those English skills and sub-skills were set into ten topics of learning that used for the basis in developing the syllabus. The topics were helpful to determine the basic competence, indicator, learning materials, learning activities, and learning source. Therefore, 26 English sub-skills were set into ten topics as follows: 1) Greeting and Welcoming, 2) Making Reservation, 3) Introducing Hotel Facilities, 4) Checking-In, 5 )Reading and Writing Email, 6) Sightseeing and Shopping, 7) Dealing with customers, 8) Dealing with customers over the telephone 9) Serving Food and Beverage, 10) Checking-Out.

Each topic above concerned with different language expression and vocabularies related to hotel context and small percentage of general English. From those topics, the students did not only learn about grammar but they also implicated the language in real life situation by doing communicative activities like role play, group discussion, as well as ask and answer. This was intended to familiarize the students with terms in offering, apologizing, suggesting, persuading, recommending, asking and giving information, and so on.

In communicative English syllabus, the learning activities focused on how language use for communicative goal. It forced the students to talk more in classroom activities. In line with Richard and Rodgers (2001), communicative activity emphasizes on communication and real-life situation. It helped students to use the language as tool of 
communication on every aspect of working condition in the hotel. So students could enhance their language skill to be more fluent and appropriate when they interact with hotel customers.

The learning activities in communicative classroom divided into two sections based on Richards and Rodgers' theory. The first was precommunicative activity and the second was communicative activity. In precommunicative, it focused on structural activity. In this section, the students learned about grammar, language expression, and vocabularies. Meanwhile, communicative activity was done after the students understood about grammar, vocabularies, and language expression that had teach by the English teachers in pre-communicative section. In communicative section, the students focused on social interaction which meant they used four English skills to reach communicative goal. They forced to produce language in classroom like in real hotel situation by using target language.

\section{CONCLUSION}

The result of needs analysis showed that the percentage of listening skill reached $94 \%$, speaking skill reached $91 \%$, reading skill reached $78 \%$, and writing skill reached $64 \%$. Those percentages reveal that listening and speaking skills were the most needed among the students of Hotel Department. Meanwhile, reading and writing skills were the least needed among the students of Hotel Department.

Due to the condition that speaking and listening skill were the most needed by the students, the syllabus was designed based on communicative approach emphasizing on communication and real-life situation. The syllabus based on communicative approach would help the students use the language as a tool of communication on every aspect of working condition in the hotel. So students could enhance their language skill to be more fluent and appropriate when they interact with hotel customers.

The contents of the communicative English syllabus concerned with language expression and vocabulary related to hotel context. The topics provided in the syllabus were: 1) Greeting and welcoming customers, 2) Making reservation, 3) Giving information about hotel, 4) Checking-in, 6) Dealing with customers, 7) Dealing with customers over telephone, 8) Sightseeing and shopping, 9) Serving food and beverage, 10) Checking-out.

\section{SUGGESTION}

Related to the aim of Hotel Department of SMK N 7 Bengkulu which is to prepare the students to work in hotel and tourism industry, the researcher suggests to ESP course designer to improve the English syllabus for Hotel Department especially for SMK N 7 Bengkulu because the existed English syllabus for English for Specific Purpose in SMK N 7 Bengkulu was still adapted from the internet.

Then, the English teachers can use the syllabus developed by the researcher as reference to improve their syllabus. It is also expected that by the time they develop the syllabus, the contents and topics of leaning materials can be varied too. So, the learning output can be maximized and the students will be ready to work in hotel industry.

The researcher also have a suggestion for further researchers who want to conduct research with the same topic, the researcher hopes that they use this research as reference for theirs. It is also expected that they develop the variables and objectives of their researches so that they can provide new findings in the field of syllabus development. 


\section{REFERENCES}

Central Bureau of Statistic. (2015). Jumlah Kedatangan Wisatawan Mancanegara ke Indonesia per Bulan Menurut Pintu Masuk. Taken from: www.bps.go.id. (30 September 2016)

Hutchinson, T. and Waters, A. (1987)

English For Specific Purposes: A

Learning Centred Approach. Cambridge: Cambridge University Press.

Helida, Vina. (2014). Model of Authentic English Teaching Materials for Law Faculty Students. Universitas Bengkulu.

Munby, J. (1978). Communicative Syllabus Design. Cambridge: Cambridge University Press.

Richards, J.C. and Rodgers, T.S. (2001) Approaches And Methods In Language Teaching. Cambridge: Cambridge University Press.

Setyaningsih, Yudi. (2009). Developing Communicative English Syllabus For Pre-Service Flight Attendant Training. Universitas Negeri Malang. Sugiyono. (2013). Metode Penelitian Kuantitatif Kualitatif dan $R \& D$. Bandung : Albabeta.

Sulastiyono. (2006). Manajemen

Penyelenggaran Hotel. Bandung:

Alfabeta

Vogt, K. and Kantelinen, R. (2013). Vocationally Oriented Language Learning Revisited. England: ELT Journal Oxford Academic. Vol. 67: 62-69 